\title{
Dealing with abiotic stresses: an integrative view of how phytohormones control abiotic stress-induced oxidative stress
}

\author{
Lucas A. Souza • Carolina C. Monteiro · Rogério F. Carvalho • Priscila L. Gratão • \\ Ricardo A. Azevedo
}

Received: 6 February 2017 / Accepted: 8 August 2017/Published online: 30 August 2017

(C) Brazilian Society of Plant Physiology 2017

\begin{abstract}
There is a very effective cross-talk between signals triggered by reactive oxygen species and the hormonal response in plants, inducing the expression of genes or activating proteins/enzymes likely to be involved in stress tolerance. Although abiotic stress responses and the role of the antioxidant system have been well explored in the literature, the understanding of the interrelationship between hormones and their effects on antioxidant system is not clear or well investigated. We attempted to scan the field of hormonal modulation of oxidative stress in plants. We feel that this topic is one of the most promising and emerging field in abiotic stress research because multiple responses can be controlled by hormones. We are presenting an overview of the more recent literature on what has been done regarding the interaction between auxin (AUX), gibberellins (GA),
\end{abstract}

L. A. Souza

Instituto Federal Goiano, Rede Arco Norte/Polo de Inovação em Bioenergia e Grãos, Campus Rio Verde, Cx. Postal 66, Rio Verde, GO CEP: 75901-970, Brazil

C. C. Monteiro · R. F. Carvalho $(\bowtie)$ · P. L. Gratão Depto de Biologia Aplicada à Agropecuária (DBAA), Univ. Estadual Paulista (UNESP), Jaboticabal,

SP CEP: 14884-900, Brazil

e-mail: rfcarval@fcav.unesp.br

\section{R. A. Azevedo}

Depto de Genética, Escola Superior de Agricultura "Luiz de Queiroz" (ESALQ), Universidade de São Paulo (USP), Cx. Postal 9, Piracicaba, SP CEP: 13418-900, Brazil cytokinins (CK), abscisic acid (ABA), ethylene (ET) and oxidative molecules and antioxidant compounds. Even knowing that several stress-responsive genes respond to hormones, some of which have already been documented showing that AUX, GA, CK, ABA and ET are part of stress signaling, a lot more is needed in order to have a clearer view of how and which hormones regulate abiotic stress responses.

Keywords Abiotic stress - Antioxidant system Hormones · Plant signaling $\cdot$ Reactive oxygen species

\section{Introduction}

Abiotic stresses can be considered as the most severe adverse conditions that plants may face. The severity of any abiotic stress can be intensified in plants because they are sessile organisms and therefore cannot move out to avoid the disturbance of plenary plant metabolism and functioning (Suzuki et al. 2014). As a consequence of facing abiotic stress situations, excessive accumulation of reactive oxygen species (ROS) is triggered, leading to a condition of oxidative stress (Azevedo et al. 2011). Normally, mitochondrial, chloroplasts and peroxisomes processes generate ROS (Mittler et al. 2004), but environmental situations that enhance accumulation of ROS generate an oxidative stress condition (Mittler 2002; Noctor et al. 2015). The uncontrolled oxidation induced or stimulated by any 
environmental stress can be overcome by cellular defense mechanisms, which comprise a variety of antioxidant enzymes, including superoxide dismutase (SOD—EC 1.15.1.1), catalase (CAT-EC 1.11.1.6), ascorbate peroxidase (APX—EC 1.11.1.11), guaiacol peroxidase that oxidases phenolic radicals forming phenoxyl (GPX-EC 1.11.1.7), glutathione peroxidase (GSHPX-EC 1.11.1.9) that uses thioredoxin and glutathione as electron donor (Herbette et al. 2007), and the glutathione regenerator glutathione reductase (GR-EC 1.8.1.7), which works together with APX, monodehydro ascorbate reductase (MDHR-EC 1.6.5.4) and dehydro ascorbate reductase (DHR-EC 1.8.5.1) in the Foyer-Halliwell-Asada cycle (Roychoudhury et al. 2012; Pandey et al. 2017). In addition, non-enzymatic processes are also important when concerning ROS scavenging such as ascorbic acid, tocopherols, flavonoids and reduced glutathione (Asada 1999). On the other hand, at low concentrations, ROS play a role as signaling molecules regulating several biological processes such as growth, development and response to biotic/abiotic stimuli in plants (Apel and Hirt 2004; Baxter et al. 2014), and together with a wide range of molecules, especially hormonal ones, form an orchestrated network of signaling response and action (Wrzaczek et al. 2011; Fraire-Velázquez et al. 2011).

Plant hormones are biochemical compounds responsible for controlling plant growth and development from germination to fruit production and seed dispersion. Thus, these compounds literally indicate how and when a plant should behave in response to environmental factors (Fraire-Velázquez et al. 2011). The hormonal control of development under abiotic stress involve a complex signaling cascade from stimuli perception to gene expression (Azevedo et al. 2012) and it is complex. Several lines of evidence are in accordance with the existence of cross-talk between ROS-dependent signaling pathway and hormonal responses, which working together allow plants to adjust its performance under biotic and abiotic stresses (Tognetti et al. 2012). Although it is known that several stress-responsive genes respond to hormones, some of which have already been documented showing that auxin (AUX), gibberellins (GA), cytokinins (CK), abscisic acid (ABA), ethylene (ET), brassinosteroids (BRs) and salicylic acid (SA) are part of stress signaling (Fraire-Velázquez et al. 2011), more information is needed in order to have a clearer view of how and which hormones regulate abiotic stress responses. Additionally, Table 1 gather most common response of antioxidant enzymes in plants subjected to different kinds of abiotic stress and the relationship with phytohormones.

\section{Drought stress}

Drought stress is responsible for great amounts of lost in production and this scenario is expected to be more frequent as we are facing global temperature changes (Harrison et al. 2014). Drought is responsible for major losses in productivity (Farooq et al. 2009; Cia et al. 2012; Boaretto et al. 2014; Medici et al. 2014), mainly due to drastic alterations in plant physiology and biochemistry. Thereby, relevant reports about several plant hormones influence on the modulation of drought-induced oxidative stress have been produced and some are commented next.

Abscisic acid (ABA) acts on several non-stressful and stressful situations during plant life, and drought stress is the most known adverse situation that is able to induce $\mathrm{ABA}$ production, consequently triggering its responses (Huang et al. 2012). It is already known that the main effect of ABA during drought stress is the induction of stomatal closure (Daszkowska-Golec and Szarejko 2013), and some researchers have demonstrated that it is signaled by ROS under ABA induction (Huang et al. 2008; Xu 2010) as well as by Reactive Nitrogen Species (RNS) (Oz et al. 2015).

The capability of ABA to regulate ROS content by regulating the activity of antioxidant enzymes, has been demonstrated by Ozfidan et al. (2012), who showed that exogenous application of ABA decreased the content of $\mathrm{H}_{2} \mathrm{O}_{2}$ in ABA-deficient mutants of Arabidopsis (Arabidopsis thaliana) (aba2-1) under osmotic stress, suggesting the possible role of this hormone during adjustment of ROS content. In the same way, a single application of ABA showed to be able to induce the activity of several antioxidant enzymes during drought stress in tobacco (Nicotiana tabacum L.) (Mýtinová et al. 2010) and also in Agrostis stolonifera and Poa pratensis plants (Yang et al. 2012). Another way of ABA-mediated antioxidative stress is by mean of induction of ABI4, a transcription factor responsible for expression induction of Zat 12 and Zat10 which in turn, specially Zat12, is required for expression of $A P X 1$ during oxidative 
Table 1 Main responses of antioxidant enzymes, non-enzymatic antioxidants and reactive oxygen species (ROS) under hormonal regulation and in response to several abiotic stresses

\begin{tabular}{|c|c|c|c|c|c|}
\hline Stress type & Hormone & $\begin{array}{l}\text { Antioxidant } \\
\text { enzyme }\end{array}$ & $\begin{array}{l}\text { Non-enzymatic } \\
\text { antioxidant }\end{array}$ & ROS & Reference \\
\hline \multirow[t]{8}{*}{ Drought } & ABA & $\uparrow \mathrm{APX}$ & & & Mýtinová et al. (2010) \\
\hline & BRs & & $\uparrow$ Tocopherol & & Bajguz and Hayat (2009) \\
\hline & & & $\uparrow$ Ascorbic acid & & \\
\hline & & & $\uparrow$ Glutathione & & \\
\hline & ET & $\uparrow \mathrm{SOD}$ & & & Wu et al. (2008) \\
\hline & SA & $\uparrow \mathrm{SOD}$ & $\downarrow$ Ascorbic acid & $\uparrow \mathrm{H}_{2} \mathrm{O}_{2}$ & Saruhan et al. (2012) \\
\hline & & $\uparrow \mathrm{CAT}$ & $\downarrow$ Glutathione & & \\
\hline & & $\uparrow \mathrm{APX}$ & & & \\
\hline \multirow[t]{3}{*}{ Osmotic } & ABA & $\uparrow \mathrm{SOD}$ & & $\downarrow \mathrm{H}_{2} \mathrm{O}_{2}$ & Ozfidan et al. (2012) \\
\hline & & $\uparrow \mathrm{CAT}$ & & & \\
\hline & & $\uparrow \mathrm{APX}$ & & & \\
\hline \multirow[t]{18}{*}{ Salt } & ABA & $\uparrow \mathrm{CAT}$ & & & Zong et al. (2009) \\
\hline & & $\uparrow \mathrm{APX}$ & & & \\
\hline & GA & $\downarrow$ SOD & & & Tuna et al. (2008) and Khan et al. (2010) \\
\hline & & $\downarrow \mathrm{POD}$ & & & \\
\hline & & $\downarrow \mathrm{PPO}$ & & & \\
\hline & & $\uparrow \mathrm{SOD}$ & & & \\
\hline & & $\uparrow \mathrm{CAT}$ & & & \\
\hline & & $\uparrow \mathrm{POD}$ & & & \\
\hline & SA & $\downarrow$ APX & & $\uparrow \mathrm{H}_{2} \mathrm{O}_{2}$ & Monteiro et al. (2011) \\
\hline & & $\uparrow \mathrm{GPX}$ & & & \\
\hline & BRs & $\uparrow \mathrm{SOD}$ & & & Carvalho et al. (2013) \\
\hline & & $\uparrow \mathrm{CAT}$ & & & \\
\hline & & $\uparrow \mathrm{APX}$ & & & \\
\hline & & $\uparrow \mathrm{GR}$ & & & \\
\hline & & $\uparrow \mathrm{SOD}$ & & & Sharma et al. (2013) \\
\hline & & $\uparrow \mathrm{GR}$ & & & \\
\hline & & $\uparrow \mathrm{APX}$ & & & \\
\hline & & $\uparrow \mathrm{GPX}$ & & & \\
\hline \multirow[t]{2}{*}{ Metal } & JA & $\uparrow \mathrm{CAT}$ & $\uparrow$ Ascorbic acid & & Piotrowska et al. (2009) \\
\hline & & $\uparrow \mathrm{APX}$ & $\uparrow$ Glutathione & & \\
\hline \multirow[t]{11}{*}{ Temperature } & ET & $\downarrow$ SOD & & $\downarrow \mathrm{O}_{2}^{-}$ & Djanaguiraman et al. (2011) \\
\hline & & $\downarrow$ CAT & & $\downarrow \mathrm{H}_{2} \mathrm{O}_{2}$ & \\
\hline & & $\downarrow$ POD & & & \\
\hline & BRs & $\uparrow \mathrm{SOD}$ & $\uparrow$ Phenolic acids & $\downarrow \mathrm{O}_{2}^{-}$ & Mazorra et al. (2002) \\
\hline & & $\uparrow \mathrm{POD}$ & & $\downarrow \mathrm{H}_{2} \mathrm{O}_{2}$ & \\
\hline & PR & $\uparrow \mathrm{CAT}$ & $\uparrow$ Ascorbic acid & & Janeczko (2012) and Genisel et al. (2013) \\
\hline & & $\uparrow \mathrm{SOD}$ & $\uparrow$ Glutathione & & \\
\hline & & $\uparrow \mathrm{GPX}$ & $\uparrow$ Proline & & \\
\hline & & $\uparrow \mathrm{CAT}$ & & & \\
\hline & & $\uparrow \mathrm{APX}$ & & & \\
\hline & & $\uparrow \mathrm{GR}$ & & & \\
\hline
\end{tabular}


Table 1 continued

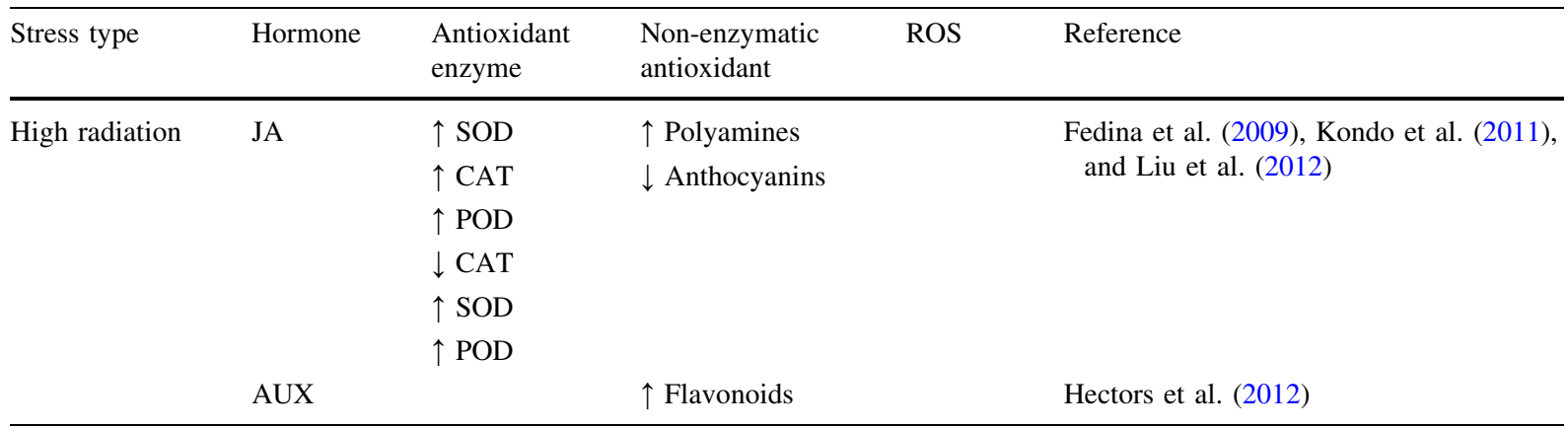

Upward arrows indicate increase in activity or concentration; downward arrows indicate decrease in activity or concentration

stress and other abiotic stresses (Koussevitzky et al. 2007).

According to Mittler and Blumwald (2015) ABA is one of the compounds that mediate the systemic acquired acclimation (SAA) by modulating ROS and calcium pool. Such a referred concept is extremely important because it is a way that plants developed to, literally, transmit to non-stressed tissues that an adverse situation is about to be established. For example, Suzuki et al. (2013) demonstrated in Arabidopsis mutants for ABA (abal-1 and abil-2) and ROS accumulation ( $r b o h D)$ that heat stress signaling by SA is not transmitted and mortality is increased, thus, confirming the interdependency of these two compounds (ABA and SA) in modulating plant responses to adverse conditions. Therefore, we wonder whether this kind of response might also be expected for drought.

Auxin (AUX) is well known for its role in cell elongation during primary growth and in modulating gene expression during development (Cohen and Gray 2007). An attempt to improve seedling ability to grow under adverse condition is seed priming with hormones, which appears to be an efficient method to improve seedling performance under stressful conditions such as observed by Carvalho et al. (2011a, b) who primed maize seeds with $10 \mathrm{ppm}$ of CEPA solution, an ethylene releaser, and observed that such a treatment conferred salt tolerance to maize seedlings (Carvalho et al. 2011a, b).

As AUX is closely related to development, this hormone needs to be tightly regulated when stress responses are concerned, especially when considering root architecture under drought stress. For instance, Passaia et al. (2014) demonstrated in Arabidopsis that
AUX is responsible for the expression induction of several transcripts of GPX. In addition, these authors have also reported the relationship between GPX activity and the induction of lateral root formation. If we link ROS inducing AUX conjugation with modulation of root architecture, it is reasonable to consider such a relationship also on crop root responses under drought stress and the possible use of this information for the selection of drought tolerant lines. Considering growth, cytokinin (CK) is a key plant hormone that can also contribute to control oxidative stress, although there is a low amount of studies concerning it.

The role of CK during drought tolerance was shown in tobacco plants overexpressing the isopenteniltransferase (ipt) gene, that were able to develop well under limited amounts of water (Rivero et al. 2007). Such a result was attributed to senescence retardation, which in turn decreased the oxidative damage. Additionally, Delatorre et al. (2012) demonstrated that the promoter PSARK (Senescence Associated Receptor Protein Kinase) fused to the ipt gene, was able to promote drought tolerance of tobacco cv. SR1 by also retarding senescence. Therefore, the action of CK to counteract drought-induced oxidative stress may be related to senescence retardation leading to decreased oxidative damage (Bhattacharjee 2005).

Brassinosteroids (BRs) are also related to plant growth and development and their metabolism can be changed under abiotic stress situations (Sasse 2003; Soares et al. 2016). Additionally, BRs can ameliorate plant response in adverse conditions such as salinity, drought, heavy metals or mineral deficiency (Khripach et al. 2000; Alam et al. 2007; Soares et al. 2016). Exogenous application of BRs was shown to modify 
activities of several antioxidant enzymes as well as to increase the concentration of non-enzymatic antioxidant such as tocopherols, ascorbic acid and glutathione in maize plants under water stress (Bajguz and Hayat 2009). On the other hand, the absence of BRs lead to a constitutive high activity of SOD and accumulation of a CAT gene transcript, which contributed to a high tolerance to oxidative stress of a biosynthetic BRdeficient mutant det2-9 of Arabidopsis (Cao et al. 2005). These authors also suggested that long-term absence of BRs can cause a constant stress situation that in turn activates the expression of defence genes such as those for CAT.

When drought-induced oxidative stress is concerned, Yuan et al. (2010) observed that application of 24-epibrassinolide (epiBR) on tomato (Solanum lycopersicum L.) plants increased ABA concentration and increased the activity of antioxidant enzymes, conferring tolerance to drought-induced oxidative stress. So, it is evident that the efficient operation of this network requires extensive metabolic crosstalk and multiple points of reciprocal control of hormones and ROS interaction (Bartoli et al. 2013) and this combination can converge for improving plant tolerance during drought condition (Zhang et al. 2011).

Ethylene (ET) acts in response to a number of stressful situations. For instance, Wu et al. (2008) demonstrated that the expression of JERF-3, a type of ERF (a transcription factor), is induced under redox unbalance and could increase tolerance of tobacco plants to drought by enhancing expression of genes related to counteract oxidative stress as well by increasing SOD activity.

In a similar manner, Sharma et al. (2010) working with tomato plants reported that ERF proteins can bind to DRE elements (region responsible for controlling expression of drought-induced genes), which are also induced by the presence of $\mathrm{ABA}$, showing the interconnection between two hormones that can act synergistically to improve plant tolerance to adverse conditions. Additionally, Trujillo et al. (2008) demonstrated that the overexpression of SodERF3, a transcription factor that promotes expression of ERF proteins, can confer tolerance to drought stress in transgenic tobacco plants since this gene is responsive to $\mathrm{ABA}$.

Furthermore, the induction of genes related to antioxidant metabolism is another way to confer tolerance to drought-induced oxidative stress by ET, which has been confirmed by Wang et al. (2012a, b), who demonstrated that in rice plants the gene OsWRI, an ET response factor, is responsive during drought stress and counteracted the oxidative stress by increasing wax production in leaves, preventing water loss and consequently oxidative damage.

Therefore, it is clear that the integration of hormone responses and changes in redox potential acts together to induce the expression of proteins able to regulate the level of tolerance to drought.

The role of salicylic acid (SA) in abiotic stress has also been well documented (Horváth et al. 2007). SA has been shown to induce $\mathrm{H}_{2} \mathrm{O}_{2}$ overproduction and its exogenous application also shown to increase the activity of antioxidant enzymes in tomato plants (Hayat et al. 2008). The $\mathrm{H}_{2} \mathrm{O}_{2}$ is known to induce the activity of several antioxidant enzymes as reported by Sousa et al. (2016) who found increased maize tolerance to drought when sprayed with $\mathrm{H}_{2} \mathrm{O}_{2}$. In addition, Noctor et al. (2012) reported the integration of GSH modulation of SA and JA signaling.

In accordance to Saruhan et al. (2012), maize plants whose leaves had been subjected to pre-treatment with SA and then subjected to drought stress, exhibited reductions in the pool of ascorbic acid and glutathione, which was explained by the increased activity of SOD, CAT and APX enzymes. Considering that SA can induce the increase in $\mathrm{H}_{2} \mathrm{O}_{2}$ content and that it is also able to regulate the expression of genes encoding antioxidant enzymes, it is believed that SA triggers a signaling cascade that confers tolerance during environmental stimulus. Interestingly, the results reported by Bandurska and Stroinski (2005) revealed that exogenous application of SA induced tolerance to drought by means of inducing plants to accumulate ABA, whose responses during drought stress is well known.

Jasmonic acid (JA) is also involved in biotic stress responses; an example is the effect of wounding damage caused by herbivory (Wasternack 2007a). However, in the case of JA, in contrast to SA, the signal transduction is mediated through mitogenactivated protein kinase (MAPK) (Wasternack 2007b). Furthermore, GSH interacts with JA transduction signal pathway, whereas SA is known to negatively regulate its response (Han et al. 2013). Agrawal et al. (2003) showed that OsBWMK1, a type of MAPK from rice plants, was induced by JA treatment and drought imposition, suggesting 
common lines of signal transduction by the hormone and an abiotic stress perception. Such a result suggests that the use of JA pre-treatments may promote drought tolerance. In another study, stimulation of a cucumber MAPK gene was reported by Xu et al. (2008), who demonstrated that the gene CsNMAPK, which encodes a type of MAPK, responded to $\mathrm{H}_{2} \mathrm{O}_{2}$ presence. Keeping in mind that oxidative stress led to an increase of the $\mathrm{H}_{2} \mathrm{O}_{2}$ content, it would be plausible to suggest that signaling by MAPK could contribute to drought tolerance as well as drought-induced oxidative stress.

Drought stress is a very important and complex abiotic stress and, to track all plants' response and tolerance mechanism to it is a great challenge. As we could see above, plant hormones can mediate several responses related to counter act oxidative stress, which are triggered by both biotic and abiotic stresses. The most important consideration is that any of these hormones act by its own, their signal cascades interact for a final response. In fact, plant response to a single environmental stress is sensed by different organs and then, the signal is transmitted to the whole plant, changing the balance of every phytohormone, in this case, drought stress which is very complex due to the several consequences that drought impose to plants.

\section{Salt stress}

It is now common knowledge that in addition to the arid and semi-arid regions of the planet, the intensive cultivation of irrigated soils gave rise to increased salinity problems. Salt stress is one of the most serious abiotic stress factors limiting crop productivity (Monteiro et al. 2011; Zörb et al. 2013; Sharma et al. 2013; Maurya and Gothandam 2014; Nimir et al. 2015), which can affect plant-water relationship through ionic and osmotic phases (Chaves et al. 2009). Furthermore, salt stress can cause oxidative stress by favoring the production or enhancing the availability of ROS, disrupting protein synthesis (Geissler et al. 2009) and photosynthetic efficiency (Mittal et al. 2012), increasing lipid peroxidation in membranes and decreasing plant productivity and growth (Hafsi et al. 2010; Monteiro et al. 2011). Moreover, salinity is associated with an increase in some hormones such as the ABA content, and a decrease in others such as AUX, CK and GA (Nimir et al. 2015).
Not surprisingly, a number of studies have shown that hormones are involved in the mediation of salt stress signaling responses. Since the 1980s, studies on the relationship between plant hormones and salinity have been more intensively conducted. An example of the early work is the one by Bozcuk (1981), who studying the seed response of tomato, barley and cotton exposed to increasing concentrations of $\mathrm{NaCl}$ (25, 50, 75, 100 and $150 \mathrm{mM})$, observed that $\mathrm{CK}$ (kinetin at concentrations of $10 \mathrm{ppm}$ ) application was not only able to alleviate the osmotic stress, but also to increase germination. A few years later, Khan and Ungar (1985) observed that exogenous applications of GA $\left(\mathrm{GA}_{3}\right.$ at concentrations of $29 \mu \mathrm{M}, 0.29 \mathrm{mM}$ and $2.9 \mathrm{mM}$ ) and $\mathrm{CK}$ (kinetin at concentrations of $4.7 \mu \mathrm{M}$, $47 \mu \mathrm{M}$ and $0.47 \mathrm{mM}$ ), whether individually or combined, were able to break salt-induced dormancy in Atriplex triangularis. Until then, a few papers essentially reported such types of responses, but none clearly explained or discussed the mechanisms involved or how these hormones were showing positive effects in reducing the negative effect of salt stress. For example, Chrominski et al. (1986) working with hypocotyl segments of mung bean (Vigna radiata) exposed to different salt solutions (0-1 M $\mathrm{NaCl}$ and $0-1 \mathrm{M} \mathrm{KCl}$ ), observed that Et production decreased with increasing concentrations of salt. Therefore, the authors suggested that changes in ET production could be an indicator of salt stress.

Kabar (1987) exposed Hordeum distichum seeds pre-treated with aqueous solutions of CK (kinetin at concentrations of $50 \mathrm{ppm}), \mathrm{GA}\left(\mathrm{GA}_{3}\right.$ at $100 \mathrm{ppm}$ concentration) and both combination, to a salt medium $(1.0,1.25,1.5$ and $1.75 \% \mathrm{NaCl})$ and allowed to germinate. The results revealed that GA not only stimulated the germination of the seeds under salt stress but also shortened the time for germination under salt conditions.

With the advances in analytical methods in the physiology, biochemistry and molecular biology fields, more aspects and a better understanding of the roles of hormones on salt stress responses were made possible and some key aspects elucidated. For instance, the study of Malibari (1993) revealed that exogenous application of ABA and CK (kinetin) in wheat under salt stress resulted in increased chlorophyll content and dry mass production as well as decreased transpiration. Another study with barley and wheat demonstrated that the expression of genes 
involved in the germination of seeds is regulated in a tissue-specific manner and it was regulated by treatments with $200 \mathrm{mM} \mathrm{NaCl}$ and plant hormones (treated with AUX-IAA/indole acetic acid, ABA, SA and MeJA/methyl jasmonate) (Hurkman and Tanaka 1996). In this study, oxalate oxidase activity, an enzyme that catalyses the conversion of oxalate to $\mathrm{CO}_{2}$ and $\mathrm{H}_{2} \mathrm{O}_{2}$, was higher during germination.

Subsequent work carried out with Citrus plants revealed that $\mathrm{ABA}$ (at $10 \mu \mathrm{M}$ ) signaling is very important for both drought and salt stress $(100 \mathrm{mM}$ $\mathrm{NaCl}$ ), because of the reduced leaf chloride concentration, Et production and leaf abscission (Arbona et al. 2006). Yan et al. (2012) who studied tobacco plants transformed with the maize ZmABI5 gene, which is homologous to the ABA-insensitive gene $(A B I)$, observed that the over-expression of the gene resulted in more sensitive plants to abiotic stresses, including to high salinity $(250 \mathrm{mM} \mathrm{NaCl})$. Yan et al. (2012) suggested that the over-expression of ZmABI5 gene induced the expression of stress-related genes encoding ROS scavenging enzymes such as CAT and APX. On the other hand, the activities of other antioxidant enzymes such as SOD and peroxidase (POD-EC 1.11.1) decreased, whereas the content of malondialdehyde (MDA) was higher in the transgenic plants when compared to the wild-type plants, a clear indication that the transgenic plants were suffering from the stress produced by excess salt. These results clearly demonstrated that over-expressing ZmABI5 plays a negative regulatory role in salt stress because the ABA signal transduction is affected. The increase in ABA activates MAPK, which in turn induces expression of antioxidant genes, such as APX and CAT (Zong et al. 2009).

Pons et al. (2013) studied the implication of ABA on the control of salt-induced cellular mechanisms leading to $\mathrm{Na}^{+}$extrusion from the cytoplasm in rice cell lines differing in salinity tolerance, by measuring the response of $\mathrm{H}^{+}$-pumps and $\mathrm{Na}^{+} / \mathrm{H}^{+}$-antiporters associated with the plasma membrane and the tonoplast to ABA (at concentration of $2 \mu \mathrm{M}$ for 5 days). These authors showed that $\mathrm{H}^{+}$-pumps and $\mathrm{Na}^{+} / \mathrm{H}^{+}$ antiporters are differently affected by $\mathrm{ABA}$ in rice under salt stress but not under control conditions. In general, under saline conditions ABA seems to affect synergistically $\mathrm{H}^{+}$pumping and antagonistically $\mathrm{Na}^{+}$ extrusion, which suggests that it may be involved in the restoration of cellular homeostasis under salt stress. ABA can contribute to maintain cytosolic $\mathrm{K}^{+}$ because of an enhanced activity of the $\mathrm{H}^{+}$-ATPase, since $\mathrm{K}^{+}$transport is affected by the electrical component of the proton motive force (Türkan and Demiral 2009). In addition, $\mathrm{K}^{+} / \mathrm{Na}^{+}$homeostasis can be achieved if the ABA signaling can induce $\mathrm{Na}^{+} / \mathrm{H}^{+}$ antiport activity (Pons et al. 2013).

GA is another hormone involved in salt tolerance. Ashraf et al. (2002) applied a foliar treatment of GA (100 $\mathrm{mg} \mathrm{L}^{-1} \mathrm{GA}_{3}$ spray) to spring wheat cultivars under salt stress and observed an increase in vegetative growth and also an enhanced accumulation of $\mathrm{Na}^{+}$and $\mathrm{Cl}^{-}$in both shoots and roots, whilst it caused an increase in photosynthetic capacity due to the increased chlorophyll content. As a conclusion, the application of $\mathrm{GA}_{3}$ enhanced water use efficiency and decreased stomatal conductance (Ashraf et al. 2002).

Tuna et al. (2008) working with maize plants observed that foliar application of $\mathrm{GA}_{3}$ (at concentration of $100 \mathrm{ppm}$ ) improved seedling growth and its establishment in saline soil conditions, which was followed by a decrease in activity of some enzymes such SOD, POD and polyphenol oxidase (PPO-EC 1.10.3.1). However, under salt stress, linseed plants (Linum usitatissimum L.) subjected to combined application of $\mathrm{CaCl}_{2}\left(10 \mathrm{mg} \mathrm{Ca} \mathrm{kg}{ }^{-1}\right)$ and $\mathrm{GA}_{3}$ $\left(10^{-6} \mathrm{M}\right)$ exhibited reversed effect of salt stress and adjusted the plants to perform normally because of increased SOD, CAT, POD activities (Khan et al. 2010).

In addition, SA participates in the regulation of physiological processes in plants such as stomatal closure, inhibition of Et biosynthesis, transpiration and photosynthesis (Khan et al. 2012). Moreover, another indirect effect of SA appears to be on the activity of antioxidant enzymes such as SOD, POD and CAT (Noreen et al. 2009). For example, in studies with tomato exposed to $100 \mathrm{mM} \mathrm{NaCl}$, Wasti et al. (2012) observed that the plants treated with $0.01 \mathrm{mM}$ SA exhibited an attenuation effect on the negative impact of salinity on plant growth. Although these authors showed that during salt stress SA induced the accumulation of proline in roots and leaves, the interaction between SA and related osmolytes is still poorly explored and it should receive more attention in future studies. Abedini and Daie-Hassani (2015) reported that two wheat cultivars tolerate high salinity $(150 \mathrm{mM})$ when $\mathrm{SA}$ is applied at a physiological concentration $(250 \mu \mathrm{M} \mathrm{SA})$ because of the induction 
of the activity of antioxidant enzymes (SOD, POD and CAT). Horváth et al. (2015) showed that with $10^{-4} \mathrm{M}$ SA the root length of tomato plants was not reduced when grown in a saline environment $(100 \mathrm{mM} \mathrm{NaCl})$ to the same extent as the control, which was correlated with a reduced Et production in root tissues in these plants in addition to the induced expression of the genes involved in ABA biosynthesis, promoting the ABA transport to the shoot.

In another report with tomato under salt stress (Monteiro et al. 2011), different tissue-dependent responses by the antioxidant system were observed during plant development. In fruits, increased $\mathrm{H}_{2} \mathrm{O}_{2}$ accumulation, reduced APX activity and enhanced GPX activity in the Et Never ripe (Nr) tomato mutant subject to $\mathrm{NaCl}$ treatment were observed. More recently, Lin et al. (2012) studied the germination of Et sensitive and insensitive mutants in Arabidopsis under high salt conditions and showed that Et is involved in the regulation of germination as an initiator of the process rather than a consequence. Et was shown to promote germination by modulating the endogenous concentration of $\mathrm{H}_{2} \mathrm{O}_{2}$ in germinating seeds under salinity.

The germination and seedling development of mutants overexpressing the EIN3 gene under high salinity (up to $200 \mathrm{mM} \mathrm{NaCl}$ ) exhibited better responses when compared to the wild genotype (Lin et al. 2013). The EIN3 gene encodes the transcriptional activator EIN3, which is activated by Et, and thus, follows the signaling of Et responses in cells. Its overexpression showed better cell signaling indicating an important role in preventing photo-oxidation to promote greening of Arabidopsis seedlings (Lin et al. 2013).

A comprehensive study on the changing levels of plant hormones during leaf senescence induced by salt stress in tomato provided important clues to the sequence of physiological events involved in this process (Ghanem et al. 2008). Initially, there is an imbalance in osmotic adjustment in cells that promote early leaf senescence, even before the massive accumulation of toxic ions. The indirect effects of $\mathrm{ABA}$, due to an initial ABA accumulation and decrease in AUX (IAA), followed by a strong and continuous decrease in CK content, certainly favor the progression of leaf senescence under salinity conditions. Furthermore, the Et precursor 1-aminocyclopropane1-carboxylic acid (ACC) may favor the accumulation of $\mathrm{Na}^{+}$at the onset of oxidative damage and the decrease in fluorescence. In another recent work with hybrid maize plants resistant and susceptible to salinity, Zörb et al. (2013) demonstrated the differences in hormone concentrations in the expansion of leaves and roots. In response to salinity (100 mM $\mathrm{NaCl}$ ), the salt-resistant maize line used increased significantly AUX (indole-3-butyric acid-IBA) concentrations in growing leaves and maintained IAA concentrations in roots. The authors suggested that these hormonal adaptations might have created favorable conditions for growth-promoting expansins, a group of cell wall proteins (Geilfus et al. 2011). Furthermore, the significant increase in the concentrations of $\mathrm{ABA}$ in the leaves of the maize resistant line under salt stress may contribute to the acidification of the apoplast, which is a prerequisite for growth.

In addition to the classical hormones, others small molecules have been studied in the transduction of signals from cell to cell when some stressful conditions occur, such as BRs. Sharma et al. (2013) conducted a study with rice seeds subjected to treatment with BR (24-epibrassinolide-EBL at concentrations of $10^{-11}, 10^{-9}$ and $10^{-7} \mathrm{M}$ ), whose seedlings were then further exposed to different concentrations of $\mathrm{NaCl}(0,75,100$, and $125 \mathrm{mM})$, a condition that resulted in improved growth. When other analyses involving the antioxidant system were performed, these authors observed increased activities of SOD, CAT, GR, APX and GPX, and also an increase in proline content in rice seedlings, whereas the rate of membrane lipid peroxidation was decreased. Carvalho et al. (2013) were also able to show that the application of exogenous BRs positively regulated the expression of $\mathrm{Cu} / \mathrm{Zn}$-SOD, CAT, APX and GR in tomato. However, during leaf senescence, the BR-deficient mutant of tomato did not induce antioxidant enzyme activities (Carvalho et al. 2013).

Several stresses can induce JA biosynthesis, which can affect negatively plant adaptation to salinity conditions (Kurotani et al. 2015). Kurotani et al. (2015) demonstrated that inactivated JA responses through the increased gene expression of $C Y P 94 C 2 b$ enhanced salt tolerance in rice. Although the number of reports published is large and only a fraction has been used in this section of the review, there is still plenty of room for research on several aspects. 


\section{Metal stress}

Toxic metals are among the main classes of abiotic stress agents for living organisms especially due to their increasing use in anthropogenic activities (Souza et al. 2014). Consequently, their release into the environment has a real potential to cause serious damage to animals and humans if they enter the food chain (Gratão et al. 2005, 2015). Such potential accumulation of a toxic metal is therefore an aspect that has to be taken always into consideration and their distribution in plant tissues/organs and during the different stages of development never neglected, especially when food crop are concerned. Their general effects on plant cells are not the subject of this review, but they can drastically affect cellular signaling and cause irreversible damage to biological systems (Gill et al. 2012), specially iron (Fe).

Iron, in its oxidized form $\left(\mathrm{Fe}^{3+}\right)$ can react with superoxide $\left(\mathrm{O}_{2}{ }^{\cdot-}\right)$ and therefore induces the formation of hydroxyl radical $\left(\mathrm{OH}^{-}\right)$by Fenton's reaction; the hydroxyl radical is very reactive and as there are no mechanism to direct conteract hydroxyl radicals, cells evolved to keep under tight control the formation of superoxide and hydrogen peroxide as well as free iron concentration inside the cell (Apel and Hirt 2004; Das and Roychoudhury 2014).

All hormonal classes have shown to include components of stress response induced by toxic metals, such as ABA (Hsu and Kao 2008), CK (Munzuroglu and Zengin 2006), BR (Hayat et al. 2007), GA (Celik et al. 2008), AUX (Zhao et al. 2011; Gratão et al. 2012), Et (Monteiro et al. 2011; Gratão et al. 2012) and JA (Noriega et al. 2012; Yu et al. 2012). According to Piotrowska et al. (2009), JA can act in a concentration-dependent manner. For instance, a low JA concentration $(0.1 \mu \mathrm{M})$ exogenously applied to Wolffiaarrhiza (Lemnaceae) plants subjected to lead $(\mathrm{Pb})$ stress activated not only CAT and APX, but also the non-enzymatic antioxidants ascorbate and glutathione, which apparently were responsible for suppressing the state of oxidative damage induced by $\mathrm{Pb}$.

In recent years, significant new information about the interaction between protective mechanisms and plant hormones during abiotic stress has been acquired through the use of the omics technologies, such as genomics and proteomics. For instance, gene expression data from the Genevestigator Arabidopsis database in response to BR treatments were compared with published microarray analysis performed on plants treated with cadmium (Cd), showing a consistent regulation of the hormone on the modulation of plant to Cd-sensitivity (Villiers et al. 2012). The effect of BRs against stress is not well understood, but it may be possible that this hormonal class might maintain the altered redox status of cells through the regulation of antioxidant activities and accumulation of osmoprotectants, such as shown in the case of Arabidopsis exposed to chromium (Cr) (Sharma et al. 2011). Recent work by Soares et al. (2016) evaluated the effects of exogenous application of 24-epibrassinolide (24-EBL) in the physiological and biochemical responses of Solanum nigrum exposed to nickel (Ni), which revealed that $\mathrm{Ni}$ did not induce a severe oxidative stress in $S$. nigrum, yet the exogenous application of the 24-EBL enhanced the plant tolerance to $\mathrm{Ni}$, which involved distinct responses by the antioxidant system.

The use of single mutants and transgenic plants has helped in elucidating a wide range of complex responses involved with plant hormones. The use of the tomato mutants $\mathrm{Nr}$, diageotropica (dgt), Et and AUX insensitive, revealed that these mutants might withstand or avoid stress imposed by $\mathrm{Cd}$ by the enhanced response of the antioxidant system (Monteiro et al. 2011; Gratão et al. 2012). Furthermore, Et can act through mechanisms which appear to be stressful and tissue-dependent (Monteiro et al. 2011), interacting with other hormones (Divi et al. 2010). On the other hand, ABA-deficient ( $a b a-1, a b a-3$ and $a b a-$ 4) and ABA-insensitive (abi2-1 and abi3-1) mutants of Arabidopsis exhibited greater Cd-induced inhibition of seed germination as opposed to the wild type (Landsberg erecta), a result that could be explained by increased sensitivity to the metal ion and higher metal uptake rates by the mutant seeds (Sharma and Kumar 2002).

The damage caused by toxic metals to the agricultural ecosystem could be solved by using plants to clean up the metal contaminated areas (Singh and Prasad 2011; Souza et al. 2013, 2015). In this context, it has been shown that plant growth regulators (PGRs) based on CK can be used to increase the metal uptake by crop plants during the phytoextraction process (Tassi et al. 2008). Moreover, according to the same authors, the increase in $\mathrm{Pb}$ and $\mathrm{Zn}$ accumulation in the upper parts of Helianthus annuus plants could be 
related to the role of PGRs based on CKs in the enhancement of plant resistance to stress. In another study the biosorption and the content of essential metabolites (proteins, monosaccharides and total carotenoids) in Chlorella vulgaris treated with $\mathrm{Pb}$ and $\mathrm{Cd}$ were higher in the presence of GA showing the protective effect of this phytohormone against heavy metal stress (Falkowska et al. 2011).

When protective responses to metal toxic stress are analyzed, the tolerance to toxic metal toxicity can also be related to the activation of GSH synthesis, suggesting that some other SH-compounds are possibly involved in toxic metal detoxification (Tian et al. 2012). In this context, Masood et al. (2012) verified in mustard (Brassica juncea) that Et can alleviate photosynthetic inhibition by maintaining high GSH synthesis and redox state (GSH/GSSG), inducing tolerance to $\mathrm{Cd}$ stress. The role of ABA was shown to contribute to the higher demand of cysteine for adaptation and protection during the early stress responses to Cd in Typha latifolia L. and Phragmites australis (Cav.) Trin. ex Steudel plants (Fediuc et al. 2005).

As already commented, there is vast literature on metal stress response and only in the last few years has more attention been dedicated to understand the role of hormones in metal stress response. Nevertheless, future research must necessarily try different approaches and invest more heavily on the understanding of the mechanisms connecting phytohormones and toxic metals particularly if there is to be further progress towards breeding for stress tolerance. For instance, the increasing industrial production of nanomaterials is an important issue to deal with, especially due to the interaction between nanoparticles (NPs) and the environment (Arruda et al. 2015). Yet, the use of these NPs may be of tremendous value in future studies on the interaction of the NPs with plants and the consequences of this interaction, including as a tool to better understand the roles of hormones on metal-induced stress. The recent report by Gratão et al. (2015) on the use of grafting to study Cd-induced stress signaling and root-to-shoot communication is another example of powerful strategies to better understand stress responses. This system appears to be particularly useful to investigate the relationship between metals and hormones in a system in which different plant parts (for instance, the scion and the rootstock) can be subjected to distinct conditions and yet, one integrated plant system evaluated together with a number of variables including the effects of the different plant hormones in the signaling process.

\section{Temperature stress}

One of the most natural common stress factor faced by plants is the effect of temperature. On Earth, the temperature can vary from several degrees below zero to over $50^{\circ} \mathrm{C}$. In addition to these natural differences in temperature between the regions of the globe, increasing industrialization since the mid nineteenth century has lead to an increase in carbon dioxide concentration, and therefore an increase in temperature. The recent discussions and climatological data are clearly indicating that the average temperature on earth is rising, which must be a major cause of concern also for agriculture in general. It is not the objective of this review to discuss climate change, although it is a subject that is extremely important, relevant and linked to this sub-section, but it is a subject that is directly linked to plant survival and performance in a changing environment. Low temperatures can reduce enzyme activity by a number of ways, including reduced metabolic rates and operation not in the optimum temperature, hardening of membranes and destabilization of protein complexes, besides the accumulation of ROS, which combined or individually, and depending on the intensity and duration of the stress, may even cause cell death (Gratão et al. 2005; Ruelland et al. 2009; Yang et al. 2015). On the other hand, high temperatures can cause water deficiency in plants by enhancing transpiration and evaporation and change the level and balance of hormone regulation (Nimir et al. 2015).

To protect cells under high temperature stress, plants need to change developmental, physiological and biochemical processes (Nimir et al. 2015), such as membrane fluidity and cytoskeleton rearrangement, increasing ROS production in cells (Ruelland and Zachowski 2010; Qu et al. 2013). For instance, Djanaguiraman et al. (2011) observed in soybean plants that high temperature increased the Et production rate and decreased SOD, CAT and POD activities. On the other hand, these authors also observed that the application of the Et perception inhibitor 1-methyl cyclopropene or 1-MCP $\left(1 \mu \mathrm{g} \mathrm{L}^{-1}\right.$ in the form of SmartFeesh $^{\mathrm{TM}}$ tablets), lowered ROS accumulation, 
whereas the activity of a number of antioxidant enzymes (CAT, SOD and POD) was enhanced. The authors suggested that Et can regulate the inhibition of membrane lipid peroxidation by decreasing $\mathrm{O}_{2}{ }^{-}$ content and $\mathrm{H}_{2} \mathrm{O}_{2}$ by increasing the activity of enzymes of the antioxidant system such as SOD, CAT and POD, and delayed leaf senescence, decreased flower abscission and increased pod set percentage. Another interesting result was found by Zinta et al. (2014) who, although it is not related to hormonal responses, demonstrated that under a rich $\mathrm{CO}_{2}$ atmosphere the high temperature stress is mitigated in Arabidopsis specially due to the higher level of antioxidants found in tissues. However, it is not reasonable to consider that hormones are part of an interplay between $\mathrm{CO}_{2}$, temperature and oxidative stress responses because it has been evident that stressrelated hormones, such as $\mathrm{ABA}$ and $\mathrm{SA}$, interact with antioxidant molecules in the protection of photosynthesis under temperature stress conditions (see review by Gururani et al. 2015; Kurepin et al. 2015).

The exogenous application of CK can also alleviate injuries caused by high temperatures in plants because it may delay leaf senescence, reducing lipid peroxidation and increasing antioxidant activity (Zhang and Ervin 2008). However, Wang et al. (2012b) working with creeping bentgrass (A. stolonifera L.), a coolseason perennial grass species of the Poaceae family, that was maintained in a $38 / 28{ }^{\circ} \mathrm{C}$ (day/night) growth chamber for 28 days, did not observe any effect of CK (trans-zeatin riboside in foliar spray treatments at concentration of 0,10 and $100 \mu \mathrm{M}$ ) on the antioxidant system. These results demonstrated that the effect of phytohormones on the antioxidant system may be related to plant species or time-length of exposure to the stress. Zhang et al. (2015) working with a chitosang-salicylic acid complex (chitosan is a linear polysaccharide consisting of $\beta$-(1-4)-2-amino-2-deoxy-Dglucan) revealed that exogenous application of this complex alleviated chilling injury and maintained better quality cucumber plants, reducing MDA content and inducing antioxidant enzymes activities such as SOD and CAT. The fruit quality parameters such as firmness, were better. Moreover, fruit treated with the chitosan-g-salicylic acid complex was bigger than the control, and exhibited higher levels of ascorbic acid and chlorophyll.

In another interesting work at temperatures above $40^{\circ} \mathrm{C}$, tomato plants subjected to exogenous application of BR (24-epibrassinolide at concentration 2.12 and $10.60 \mathrm{nM}$ ) exhibited higher activity of SOD and POD in leaves (Mazorra et al. 2002). Moreover, application of exogenous BRs plays an important role in the protection of the photosynthetic apparatus against damage caused by high temperature (Dhaubhadel et al. 1999). BRs can be a stimulus to increase the synthesis of photosynthetic pigments, a help against the PSII over - excitation and perhaps from a loss of integrity in the thylakoid membrane. So, it is possible to say that BRs maintain high efficiency of energy use of photons absorbed by maintaining the balance of excitation distribution between PSII and PSI (Zhang et al. 2013). In another study El-Bassiony et al. (2012) working with snap beans (Phaseolus vulgaris) treated with the BR analogue $\beta$-sitosterol (at a concentration of $25 \mathrm{ppm}$ ) and under high temperature (over $30^{\circ} \mathrm{C}$ ), observed an increase in the total soluble amino acid content in leaves and total phenolic acids in comparison to the control treatment. In fact, exogenous steroids have also been shown to be one more group of compounds, which can be involved in the control of the responses to stresses suffered by plants, which can increase the ability to regenerate Rubisco under high temperature stress (Ogweno et al. 2008).

Among the group of steroids, progesterone (PR) has been studied in plants and shown to promote or inhibit growth of roots and leaves, effects that appear to be dependent upon concentration. Moreover, PR has been reported as a steroid that stimulates the activity of antioxidant enzymes such as CAT, and may be connected with the metabolism of the GA (Janeczko 2012). For instance, Genisel et al. (2013) studied the influence of foliar PR application $\left(10^{-7} \mathrm{~mol} \mathrm{~L}^{-1}\right)$ on chilling tolerance of chickpea seedlings. The results revealed that the chilling stress induced increased activities of the antioxidant enzymes studied (SOD, GPX, CAT, APX and GR), as well as the level of some non-enzymatic antioxidant compounds (ascorbic acid, glutathione and proline), and also affected the oxidative stress indicators, such as $\mathrm{O}_{2}^{-}$production, electrolyte leakage, $\mathrm{H}_{2} \mathrm{O}_{2}$ and MDA contents. The application of PR has also been shown to enhance chilling tolerance in chickpea seedlings because of the increase in activity of antioxidant enzymes as well the elevation of the level of antioxidant compounds, and the decrease in leaf relative water content (RLWC) (Genisel et al. 2013). 
Analysis of the transcriptional profile of Populus simonii in response to cold stress revealed that some genes were up-regulated in response to temperature stimulus, ROS, and hormone stimulus in leaves. On the other hand, cold stress also repressed a number of genes including some involved in cellular nitrogen compounds from metabolic processes, such as photosynthesis and generation of precursor metabolites and energy. Several genes involved in photosynthesis, calcium/calmodulin-mediated signal transduction, ABA homeostasis and transport, and antioxidant defense systems were also differentially expressed (Song et al. 2013). These results indicated that the increase in transcripts related to signal transduction and antioxidant defense systems through its complex signaling cascade and removal of ROS may play a role in the protection of Pinus simonii under conditions of low temperature stress (Song et al. 2013).

JA and Et can act together to regulate plant defense against cold and freezing stress, and heat tolerance (Kazan 2015). Plants exposed to low and high temperatures exhibited elevated endogenous JA levels, whereas the Et overproducing mutant etol exhibited reduced freezing tolerance, indicating a negative effect of Et on cold tolerance (Kazan 2015). However, JA signaling appears to involve a more complex hormonal interaction since JA stimulated the expression of crucial enzymes for ABA biosynthesis, as well as alleviated injury by cold because it also induced cellular alkalinization, which occured through increase in intracellular $\mathrm{pH}$ in stomatal guard cells and preceded stomatal closure (Hossain et al. 2011). Moreover, in a comparative transcriptome analysis of rice seedlings under cold stress, Yang et al. (2015) observed increases in the expression of $\mathrm{ABA}$ and JA genes and polyamines, which suggested that a coordinated action established the state of rice cold stress tolerance.

It is not yet possible to say how plant hormones act on the antioxidant system of plants in order to provide a concerted action against the oxidative effects caused by high or low temperature. This complexity can be enhanced if high or low temperature is associated with another abiotic stress, specifically high radiation which is the subject discussed below. Thus, further studies are necessary to better understand the mechanisms involved and how to change the regulation of pathways in order to obtain plants more resistant to adverse weather variations like temperature.

\section{High UV-B stress}

Due to the high energy content, ultraviolet (UV), such as UV-B (290-315 $\mathrm{nm}$ ) radiation, can induce a range of photo-oxidation and photo-modification reactions, including DNA damage (Britt 2004). Many of these adverse effects of UV-B on plant cells are triggered by the generation of ROS, which in turn affects negatively several physiological responses (Cakirlar et al. 2011). For example, the most known physiological process involving the production of ROS by UV-B radiation is the inhibition of photosynthesis (Albert et al. 2011; Foyer and Shigeoka 2011). Plants have evolved efficient mechanisms to protect themselves against UV-B-induced stress and in a very similar way to other types of stresses, with the most evident protective mechanisms being the enhancement of enzymatic and non-enzymatic ROS scavenger enzymes and molecules. More specifically in the case of radiation, the accumulation of non-enzymatic compounds, such as UV-absorbing phenolic molecules (e.g. anthocyanins) in epidermal tissues (Chalker-Scott 1999), which can act as antioxidants and/or sunscreen, decreasing penetration of UV-B into the tissues (Jenkins 2009), has been reported.

Although it is not surprising that hormones participate in stress signaling induced by UV-B, this topic is still very scarce and elusive despite some efforts which showed that hormones can alleviate the high radiation stress through the modulation of antioxidant compounds. For example, in Hordeum vulgare JA was shown to act as a mediator in plant defense through the induction of SOD and POD activities after UV-B treatment (Fedina et al. 2009). In accordance with this, UV-C treated leaves of Malus domestica exhibited increased JA and polyamines contents, well-known effective antioxidants (Kondo et al. 2011). However, the hormonal control of antioxidants profile induced by UV-B seems to be complex since virtually all other hormones can be involved in this response, such as Et and ABA, which were shown to control polyamines accumulation, as observed in Arabidopsis rosettes (Rakitin et al. 2009). Moreover, during UV-B irradiation the expression of defence genes, such as for chalcone synthase $(\mathrm{CHS})$, which is a key enzyme for phenolic compounds biosynthesis (Alokam et al. 2002; Lozovaya et al. 2007), were decreased in Arabidopsis mutants deficient in the biosynthetic pathway of BR (det2, diml and $c p d)$ and the BR 
insensitive mutant (bril) (Savenstrand et al. 2004), indicating the need for a complete BR pathway in UV$\mathrm{B}$ stress signaling. However, the control of CHS expression triggered by UV-B seems to involve other hormones. For instance, the ein2-1 mutant of Arabidopsis, which is insensitive to Et, lead to constitutive activation of CHS under UV-B and consequently enhanced UV-B tolerance (Sun et al. 2011), indicating that Et can mediate the UV-B response through the modulation of CHS gene expression. More recently AUX was also shown to control UV-mediated accumulation of flavonoids. Hectors et al. (2012) verified that the axr4-1 influx mutant of Arabidopsis contained low levels of UV-screening flavonoids, displaying stronger stress morphological responses, such as decreased leaf expansion.

These reports point towards a puzzling network of hormonal regulation of protective molecules accumulation/activity induced by UV-B radiation. In fact, it was recently shown in wheat (Triticum aestivum) seedlings that during UV-B treatment, exogenous JA reduced CAT activity and anthocyanin content, but increased SOD and POD activities (Liu et al. 2012). This complexity is even higher if one considers that a wide range of molecules participate in UV signaling, which were shown to interact with hormones, such as $\mathrm{H}_{2} \mathrm{O}_{2}$ (He et al. 2011), nitric oxide (Tossi et al. 2009) and photoreceptors (Carvalho et al. 2011b). In fact, the last ones seem to be fundamental factors in the UV-B stress signaling. For example, Gavassi et al. (2017) recently showed that phyB1 and phyB2 mutants of tomato are more tolerant to UV-B stress. Thus, in order to better understand hormonal modulation of UV stress many efforts are still needed.

\section{Epilogue}

The elucidation of mechanisms by which hormones regulate oxidative abiotic stress is very complex due to four main issues: (1) it has been assumed that hormones act as secondary messengers for the induction of an antioxidant defense system in stressed plants and thereby could effectively scavenge ROS in plants under stress leading to reduced levels (Ogweno et al. 2008; Zhang and Xing 2008); (2) although there are enhanced activities of antioxidant enzymes in plants treated with exogenous hormones, high ROS levels can still be produced and maintained (Hung and Kao
2004; Cao et al. 2009; Parra-Lobato et al. 2009); (3) a wide range of stress-associated genes can be induced by hormones (O'Donnell et al. 2003; Uquillas et al. 2004; Blanco et al. 2005), primarily because the activation of these genes can result in the induction of ROS, which can induce stress genes resulting in a complex biochemical network (Torres et al. 2002; Moon et al. 2003; Seo et al. 2007); (4) signaling stress can be accompanied by different forms of biochemical regulation due to exogenous hormones. Thus, when applied at physiological concentrations, these substances may cause a temporary low level of oxidative stress in plants, which acts as a hardening process. This low stress condition can improve the antioxidant capacity of plants and help to induce the synthesis of protective compounds. On the other hand, overdose, repeated or prolonged application can cause irreversible disturbance of plant metabolism. Certainly, these issues fall into the multifaceted responses which are behind the hormonal control of oxidative stress.

Acknowledgements We would like to acknowledge Fundação de Amparo à Pesquisa do Estado de São Paulo (FAPESPBrazil), Conselho Nacional de Desenvolvimento Científico e Tecnológico (CNPq-Brazil) and Coordenação de Aperfeiçoamento de Pessoal de Nível Superior (CAPESBrazil) for the continuous financial support over the years to our projects on this and related subjects.

Authors contribution The following authors Lucas, Carolina, Rogério, Priscila and Ricardo equally contributed to the manuscript elaboration and organization. Besides, several critical readings during manuscript elaboration until conclusion were performed by Ricardo.

\section{References}

Abedini M, Daie-Hassani B (2015) Salicylic acid affects wheat cultivars antioxidant system under saline and non-saline condition. Russ J Plant Physiol 62:604-610

Agrawal GK, Tamogami S, Iwahashi H, Agrawal VP, Rakwal R (2003) Transient regulation of jasmonic acid-inducible rice MAP kinase gene (OsBWMK1) by diverse biotic and abiotic stresses. Plant Physiol Biochem 41:355-361

Alam MM, Hayat S, Ali B, Ahmad A (2007) Effect of 28-homobrassinolide treatment on nickel toxicity in Brassica juncea. Photosynthetica 45:139-142

Albert KR, Mikkelsen TN, Ro-Poulsen H, Arndal MF, Michelsen A (2011) Ambient UV-B radiation reduces PSII performance and net photosynthesis in high Arctic Salix arctica. Environ Exp Bot 73:10-18

Alokam S, Li Y, Li W, Chinnappa CC, Reid DM (2002) Photoregulation of phenylalanine ammonia-lyase (PAL) and 
chalcone synthase (CHS) in the accumulation of anthocyanin in alpine and prairie ecotypes of Stellaria longipes under varied R/FR. Physiol Plant 116:531-538

Apel K, Hirt H (2004) Reactive oxygen species: metabolism, oxidative stress, and signal transduction. Annu Rev Plant Biol 55:373-399

Arbona V, Lopez-Climent MF, Mahouachi J, Perez-Clemente RM, Abrams SR, Gomez-Cadenas A (2006) Use of persistent analogs of abscisic acid as palliatives against salt stress induced damage in citrus plants. J Plant Growth Regul 25:1-9

Arruda SCC, Silva ALD, Galazzi RM, Azevedo RA, Arruda MAZ (2015) Nanoparticles applied to plant science: a review. Talanta 131:693-705

Asada K (1999) The water-water cycle in chloroplasts: scavenging of active oxygens and dissipation of excess photons. Ann Rev Plant Phys 50:601-639

Ashraf M, Karim F, Rasul E (2002) Interactive effects of gibberellic acid $\left(\mathrm{GA}_{3}\right)$ and salt stress on growth, ion accumulation and photosynthetic capacity of two spring wheat (Triticum aestivumL.) cultivars differing in salt tolerance. Plant Growth Regul 36:49-59

Azevedo RA, Carvalho RF, Cia MC, Gratão PL (2011) Sugarcane under pressure: an overview of biochemical and physiological studies of abiotic stress. Trop Plant Biol 4:42-51

Azevedo RA, Gratão PL, Monteiro CC, Carvalho RF (2012) What is new in the research on cadmium-induced stress in plants? Food Energy Secur 1:133-140

Bajguz A, Hayat S (2009) Effects of brassinosteroids on the plant responses to environmental stresses. Plant Physiol Biochem 47:1-8

Bandurska H, Stroinski A (2005) The effect of salicylic acid on barley response to water deficit. Acta Physiol Plant 27:379-386

Bartoli CG, Casalongué CA, Simontacchi M, Marquez-Garcia B, Foyer CH (2013) Interactions between hormone and redox signalling pathways in the control of growth and cross tolerance to stress. Environ Exp Bot 94:73-88

Baxter A, Mittler R, Suzuki N (2014) ROS as key players in plant stress signalling. J Exp Bot 65:1229-1240

Bhattacharjee S (2005) Reactive oxygen species and oxidative burst: roles in stress, senescence and signal transduction in plants. Curr Sci India 89:1113-1121

Blanco F, Garreton V, Frey N, Dominguez C, Perez-acle T, van Der Straeten D, Jordana X, Holuigue L (2005) Identification of NPR1-dependent genes early induced by salicylic acid treatment in Arabidopsis. Plant Mol Biol 59:927-944

Boaretto LF, Carvalho G, Borgo L, Creste S, Landell MGA, Mazzafera P, Azevedo RA (2014) Water stress reveals differential antioxidant responses of tolerant and non-tolerant sugarcane genotypes. Plant Physiol Biochem 74:165-175

Bozcuk S (1981) Effects of kinetin and salinity on germination of tomato, barley and cotton seeds. Ann Bot 48:81-84

Britt A (2004) Repair of DNA damage induced by solar UV. Photosynth Res 81:105-112

Cakirlar H, Cicek N, Ekmekci Y (2011) Is the induction of $\mathrm{H}_{2} \mathrm{O}_{2}$-detoxifying antioxidant enzyme activities sufficient to protect barley cultivars from oxidant stress by UV-B irradiation alone or pretreatment with high temperature and $\mathrm{NaCl}$ ? Turk J Biol 35:59-68

Cao SQ, Xu QT, Cao YJ et al (2005) Loss-of-function mutations in DET2 gene lead to an enhanced resistance to oxidant stress in Arabidopsis. Physiol Plant 123:57-66

Cao SF, Zheng YH, Wang KT, Jin P, Rui HJ (2009) Methyl jasmonate reduces chilling injury and enhances antioxidant enzyme activity in postharvest loquat fruit. Food Chem 115:1458-1463

Carvalho RF, Piotto FA, Schmidt D, Peters LP, Monteiro CC, Azevedo RA (2011a) Seed priming with hormones does not alleviate induced oxidative stress in maize seedlings subjected to alt stress. Sci Agric 68:598-602

Carvalho RF, Campos ML, Azevedo RA (2011b) The Role of phytochrome in stress tolerance. J Integr Plant Biol 53:920-929

Carvalho RF, Monteiro CC, Caetano AC, Dourado MN, Gratão PL, Haddad CRB, Peres LEP, Azevedo RA (2013) Leaf senescence in tomato mutants as affected by irradiance and phytohormones. Biol Plant 57:749-757

Celik A, Unyayar S, Cekic FO, Guzel A (2008) Micronucleus frequency and lipid peroxidation in Allium sativum root tip cells treated with gibberellic acid and cadmium. Cell Biol Toxicol 24:159-164

Chalker-Scott L (1999) Environmental significance of anthocyanins in plant stress responses. Photochem Photobiol 70:1-9

Chaves MM, Flexas J, Pinheiro C (2009) Photosynthesis under drought and salt stress: regulation mechanisms from whole plant to cell. Ann Bot 103:551-560

Chrominski A, Khan MA, Weber DJ, Smith BN (1986) Ethylene and ethane production in response to salinity stress. Plant Cell Environ 9:687-691

Cia MC, Guimarães ACR, Medici LO, Chabregas SM, Azevedo RA (2012) Antioxidant responses to water deficit by drought-tolerant and -sensitive sugarcane varieties. Ann Appl Biol 161:313-324

Cohen JD, Gray WM (2007) Auxin metabolism and signaling. In: Hedden P, Thomas SG (eds) Plant hormone signaling. Annual plant reviews. Blackwell Publishing Ltd, Oxford, pp 37-66

Das K, Roychoudhury A (2014) Reactive oxygen species (ROS) and response of antioxidants as ROS-scavengers during environmental stress in plants. Front Environ Sci 2:53

Daszkowska-Golec A, Szarejko I (2013) Open or close the gate - stomata action under the control of phytohormones in drought stress conditions. Front Plant Sci 4:138

Delatorre CA, Cohen Y, Liu L, Peleg Z, Blumwald E (2012) The regulation of the SARK promoter activity by hormones and environmental signals. Plant Sci 193:39-47

Dhaubhadel S, Chaudhary S, Dobinson KF, Krishna P (1999) Treatment with 24-epibrassinolide, a brassinosteroid, increases the basic thermo tolerance of Brassica napusand tomato seedlings. Plant Mol Biol 40:333-342

Divi U, Rahman T, Krishna P (2010) Brassinosteroid-mediated stress tolerance in Arabidopsis shows interactions with abscisic acid, ethylene and salicylic acid pathways. BMC Plant Biol 10:151

Djanaguiraman M, Prasad PVV, Al-Khatib K (2011) Ethylene perception inhibitor 1-MCP decreases oxidant damage of leaves through enhanced antioxidant defense mechanisms 
in soybean plants grown under high temperature stress. Environ Exp Bot 71:215-223

El-Bassiony AM, Ghoname AAA, El-Awadi ME, Fawzy ZF, Gruda N (2012) Ameliorative effects of brassinosteroids on growth and productivity of snap beans grown under high temperature. Gesunde Pflanzen 64:175-182

Falkowska M, Pietryczuk A, Piotrowska A, Bajguz A, Grygoruk A, Czerpak R (2011) The effect of gibberellic acid (GA(3)) on growth, metal biosorption and metabolism of the green algae Chlorella vulgaris (Chlorophyceae) Beijerinck exposed to cadmium and lead stress. Pol J Environ Stud 20:53-59

Farooq M, Wahid A, Kobayashi N, Fujita D, Basra SMA (2009) Plant drought stress: effects, mechanisms and management. Agron Sustain Dev 29:185-212

Fedina I, Nedeva D, Georgieva K, Velitchkova M (2009) Methyl Jasmonate counteract UV-B stress in barley seedlings. J Agron Crop Sci 195:204-212

Fediuc E, Lips SH, Erdei L (2005) O-acetylserine (thiol) lyase activity in Phragmites and Typha plants under cadmium and $\mathrm{NaCl}$ stress conditions and the involvement of $\mathrm{ABA}$ in the stress response. J Plant Physiol 162:865-872

Foyer CH, Shigeoka S (2011) Understanding oxidant stress and antioxidant functions to enhance photosynthesis. Plant Physiol 155:93-100

Fraire-Velázquez S, Rodríguez-Guerra R, Sánchez-Calderón L (2011) Abiotic and biotic stress response crosstalk in plants. In: Shanker A, Venkateswarlu B (eds) Abiotic stress response in plants-physiological, biochemical and genetic perspectives. InTech, Croatia, pp 3-26. doi:10. $5772 / 23217$

Gavassi Marina A, Monteiro Carolina C, Campos Marcelo Lattarulo, Melo Hyrandir C, Carvalho Rogério F (2017) Phytochromes are key regulators of abiotic stress responses in tomato. Sci Hortic 222:126-135

Geilfus CM, Zörb C, Neuhaus C, Hansen T, Lüthen H, Mühling KH (2011) Differentialtranscript expression of wall-loosening candidates in leaves of maize cultivars differing in salt resistance. J Plant Growth Regul 30:387-395

Geissler N, Hussin S, Koyro HW (2009) Interactive effects of $\mathrm{NaCl}$ salinity and elevated atmospheric $\mathrm{CO}_{2}$ concentration on growth, photosynthesis, water relations and chemical composition of the potential cash crop halophyte Aster tripolium L. Environ Exp Bot 65:220-231

Genisel M, Turk H, Erdal S (2013) Exogenous progesterone application protects chickpea seedlings against chillinginduced oxidant stress. Acta Physiol Plant 35:241-251

Ghanem ME, Albacete A, Martinez-Andújar C, Acosta M, Romero-Aranda R, Dodd IC, Lutts S, Pérez-Alfocea F (2008) Hormonal changes during salinity-induced leaf senescence in tomato (Solanum lycopersicum L.). J Exp Bot 59:3039-3050

Gill SS, Khan NA, Tuteja N (2012) Cadmium at high dose perturbs growth, photosynthesis and nitrogen metabolism while at low dose it up regulates sulfur assimilation and antioxidant machinery in garden cress (Lepidium sativum L.). Plant Sci 182:112-120

Gratão PL, Polle A, Lea PJ, Azevedo RA (2005) Making the life of heavy metal-stressed plants a little easier. Funct Plant Biol 32:481-494
Gratão PL, Monteiro CC, Carvalho RF, Tezotto T, Piotto FA, Peres LEP, Azevedo RA (2012) Biochemical dissection of diageotropica and Never ripe tomato mutants to $\mathrm{Cd}$ stressful conditions. Plant Physiol Biochem 56:79-96

Gratão PL, Monteiro CC, Tezotto T, Carvalho RF, Alves LR, Peters LP, Azevedo RA (2015) Cadmium stress antioxidant responses and root-to-shoot communication in grafted tomato plants. Biometals 28:803-816

Gururani MA, Tapan Mohanta K, Bae H (2015) Current understanding of the interplay between phytohormones and photosynthesis under environmental stress. Int J Mol Sci 16:19055-19085

Hafsi C, Romero-Puertas MC, Gupta DK, Del Río LA, Sandalio LM, Abdelly C (2010) Moderate salinity enhances the antioxidant response in the halophyte Hordeum maritimum L. under potassium deficiency. Environ Exp Bot 69:129-136

Han Y, Mhamdi A, Chaouch S, Noctor G (2013) Regulation of basal and oxidative stress-triggered jasmonic acid-related gene expression by glutathione. Plant Cell Environ 36:1135-1146

Harrison MT, Tardieu F, Dong Z, Messina CD, Hammer GL (2014) Characterizing drought stress and trait influence on maize yield under current and future conditions. Glob Change Biol 20:867-878

Hayat S, Ali B, Hasan SA, Ahmad A (2007) Brassinosteroid enhanced the level of antioxidants under cadmium stress in Brassica juncea. Environ Exp Bot 60:33-41

Hayat S, Hasan SA, Fariduddin Q, Ahmad A (2008) Growth of tomato (Lycopersicon esculentum) in response to salicylic acid under water stress. J Plant Interact 3:297-304

He J, Yue X, Wang R, Zhang Y (2011) Ethylene mediates UVB-induced stomatal closure via peroxidase-dependent hydrogen peroxide synthesis in Vicia faba L. J Exp Bot 62:2657-2677

Hectors K, van Oevelen S, Guisez Y, Prinsen E, Jansen MAK (2012) The phytohormone auxin is a component of the regulatory system that controls UV-mediated accumulation of flavonoids and UV-induced morphogenesis. Physiol Plant 145:594-603

Herbette S, Roeckel-Drevet P, Drevet JR (2007) Seleno-independent glutathione peroxidases. FEBS J 274:2163-2180

Horváth E, Szalai G, Janda T (2007) Induction of abiotic stress tolerance by salicylic acid signaling. J Plant Growth Regul 26:290-300

Horváth E, Csiszár J, Gallé A, Poór P, Szepesi A, Tari I (2015) Hardening with salicylic acid induces concentration-dependent changes in abscisic acid biosynthesis of tomato under salt stress. J Plant Physiol 183:54-63

Hossain MA, Munemasa S, Uraji M, Nakamura Y, Mori IC, Murata Y (2011) Involvement of endogenous abscisic acid in methyl jasmonate-induced stomatal closure in Arabidopsis. Plant Physiol 156:430-438

Hsu YT, Kao CH (2008) Distinct roles of abscisic acid in rice seedlings during cadmium stress at high temperature. Bot Stud 49:335-342

Huang D, Wu W, Abrams SR, Cutler AJ (2008) The relationship of drought-related gene expression in Arabidopsis thaliana to hormonal and environmental factors. J Exp Bot 59:2991-3007 
Huang G-T, Ma S-L, Bai L-P, Zhang L, Ma H, Jia P, Liu J, Zhong M, Guo Z-F (2012) Signal transduction during cold, salt, and drought stresses in plants. Mol Biol Rep 39:969-987

Hung KT, Kao CH (2004) Nitric oxide acts as an antioxidant and delays methyl jasmonate-induced senescence of rice leaves. J Plant Physiol 161:43-52

Hurkman WJ, Tanaka CK (1996) Effect of salt stress on germin gene expression in barley roots. Plant Physiol 110:971-977

Janeczko A (2012) The present and activity of progesterone in the plants kingdom. Steroids 77:169-173

Jenkins GI (2009) Signal transduction in responses to UV-B radiation. Ann Rev Plant Biol 60:407-431

Kabar K (1987) Alleviation of salinity stress by plant growth regulators on seed germination. J Plant Physiol 128:179-183

Kazan K (2015) Diverse roles of jasmonates and ethylene in abiotic stress tolerance. Trends Plant Sci 20:219-229

Khan MA, Ungar IA (1985) The role of hormones in regulating the germination of polymorphic seeds and early seedling growth of Atriplex triangularis under saline conditions. Physiol Plant 63:109-113

Khan MN, Siddiqui MH, Mohammad F, Naeem M, Masroor M, Khan A (2010) Calcium chloride and gibberellic acid protect linseed (Linum usitatissimum $\mathrm{L}$.) from $\mathrm{NaCl}$ stress by inducing antioxidant defence system and osmoprotectant accumulation. Acta Physiol Plant 32:121-132

Khan SU, Bano A, Din J, Gurmani AR (2012) Abscisic acid and salicylic acid seed treatment as potent inducer of drought tolerance in wheat (Triticum aestivum L.). Pak J Bot 44:43-49

Khripach V, Zhabinskii V, De Groot A (2000) Twenty years of brassinosteroids: steroidal plant hormones warrant better crops for the XXI century. Ann Bot 86:441-447

Kondo S, Fiebig A, Okawa K, Ohara H, Kowitcharoen L, Nimitkeatkai H, Kittikorn M, Kim M (2011) Jasmonic acid, polyamine, and antioxidant levels in apple seedlings as affected by Ultraviolet-C irradiation. Plant Growth Regul 64:83-89

Koussevitzky S, Nott A, Mockler TC, Hong F, Sachetto-Martins G, Surpin M, Lim J, Mittler R, Chory J (2007) Signals from chloroplasts converge to regulate nuclear gene expression. Science 316:715-719

Kurepin LV, Ivanov AG, Zaman M, Pharis RP, Allakhverdiev SI, Hurry V, Hüner NPA (2015) Stress-related hormones and glycinebetaine interplay in protection of photosynthesis under abiotic stress conditions. Photosynth Res 126:221-235

Kurotani K-I, Hayashi K, Hatanaka S et al (2015) Elevated levels of CYP94 family gene expression alleviate the jasmonate response and enhance salt tolerance in rice. Plant Cell Physiol 56:779-789

Lin Y, Wang J, Zu Y, Tang Z (2012) Ethylene antagonizes the inhibition of germination in Arabidopsis induced by salinity by modulating the concentration of hydrogen peroxide. Acta Physiol Plant 34:1895-1904

Lin Y, Yang L, Chen D, Zu Y, Tang Z (2013) A role for Ethylene-Insensitive 3 in the regulation of hydrogen peroxide production during seed germination under high salinity in Arabidopsis. Acta Physiol Plant 35:1701-1706
Liu X, Chi H, Yue M, Zhang X, Li W, Jia E (2012) The regulation of exogenous jasmonic acid on UV-B stress tolerance in wheat. J Plant Growth Regul 31:436-447

Lozovaya VV, Lygin AV, Zernova OV, Ulanov AV, Li SX, Hartman GL, Widholm JM (2007) Modification of phenolic metabolism in soybean hairy roots through down regulation of chalcone synthase or isoflavone synthase. Planta 225:665-679

Malibari AA (1993) The interactive effects between salinity, abscisic acid and kinetin on transpiration, chlorophyll content and growth of wheat plant. Indian J Plant Physiol 36:232-235

Masood A, Iqbal N, Khan NA (2012) Role of ethylene in alleviation of cadmium-induced photosynthetic capacity inhibition by sulphur in mustard. Plant Cell Environ 35:524-533

Maurya VK, Gothandam KM (2014) Factors influencing the salt stress tolerance in plants-an overview. Res J Biotechnol 9:79-88

Mazorra LM, Nunez M, Hechavarria M, Coll F, Sanchez-Blanco MJ (2002) Influence of brassinosteroids on antioxidant enzymes activity in tomato under different temperatures. Biol Plant 45:593-596

Medici LO, Reinert F, Carvalho DF, Kozak M, Azevedo RA (2014) What about keeping plants well watered? Environ Exp Bot 99:38-42

Mittal S, Kumari N, Sharma V (2012) Differential response of salt stress on Brassica juncea: photosynthetic performance, pigment, proline, D1 and antioxidant enzymes. Plant Physiol Biochem 54:17-26

Mittler R (2002) Oxidative stress, antioxidants and stress tolerance. Trends Plant Sci 7:405-410

Mittler R, Blumwald E (2015) The roles of ROS and ABA in systemic acquired acclimation. Plant Cell 27:64-70

Mittler R, Vanderauwera S, Gollery M, Van Breusegem F (2004) Reactive oxygen gene network of plants. Trends Plant Sci 9:490-498

Monteiro CC, Carvalho RF, Gratão PL, Carvalho G, Tezotto T, Medici LO, Peres LEP, Azevedo RA (2011) Biochemical responses of the ethylene-insensitive Never ripe tomato mutant subjected to cadmium and sodium stresses. Environ Exp Bot 71:306-320

Moon H, Lee B, Choi G et al (2003) NDP kinase 2 interacts with two oxidant stress-activated MAPKs to regulate cellular redox state and enhances multiple stress tolerance in transgenic plants. Proc Natl Acad Sci USA 100:358-363

Munzuroglu O, Zengin FK (2006) Effect of cadmium on germination, coleoptile and root growth of barley seeds in the presence of gibberellic acid and kinetin. J Environ Biol 27:671-677

Mýtinová Z, Motyka V, Haisel D, Gaudinová A, Lubovská Z, Wilhelmová N (2010) Effect of abiotic stresses on the activity of antioxidant enzymes and contents of phytohormones in wild type and AtCKX2 transgenic tobacco plants. Biol Plant 54:461-470

Nimir NEA, Lu S, Zhou G, Guo W, Ma B, Walg Y (2015) Comparative effects of gibberellic acid, kinetin and salicylic acid on emergence, seedling growth and the antioxidant defence system of sweet sorghum (Sorghum bicolor) under salinity and temperature stresses. Crop Pasture Sci 66:145-157 
Noctor G, Mhamdi A, Chaouch S, Han YI, Neukermans J, Marquez-Garcia B, Queval G, Foyer CH (2012) Glutathione in plants: an integrated overview. Plant Cell Environ 35:454-484

Noctor G, Lelarge-Trouverie C, Mhamdi A (2015) The metabolomics of oxidative stress. Phytochemistry 112:33-53

Noreen S, Ashraf M, Hussain M, Jamil A (2009) Exogenous application of Salicylic acid enhances antioxidative capacity in salt stressed sunflower (Helianthus annus L.) plants. Pak J Bot 41:473-479

Noriega G, Santa Cruz D, Batlle A, Tomaro M, Balestrasse K (2012) Hemeoxygenase is involved in the protection exerted by jasmonic acid against cadmium stress in soybean roots. J Plant Growth Regul 31:79-89

O’Donnell PJ, Schmetz E, Block A, Miersch O, Wasternach C, Jones JB, Klee HJ (2003) Multiple hormones act sequentially to mediate a susceptible tomato pathogen defense response. Plant Physiol 133:1181-1189

Ogweno JO, Song XS, Shi K, Hu WH, Mao WH, Zhou YH, Yu JQ, Nogués S (2008) Brassinosteroids alleviate heat-induced inhibition of photosynthesis by increasing carboxylation efficiency and enhancing antioxidant systems in Lycopersicon esculentum. J Plant Growth Regul 27:49-54

Oz MT, Eyidogan F, Yucel M, Öktem HA (2015) Fuctional role of nitric oxide under abiotic stress conditions. In: Khan MN, Mobin M, Mohammad F, Corpas FJ (eds) Nitric oxide action in abiotic stress responses in plants. Springer, Cham, pp 193-219

Ozfidan C, Turkan I, Sekmen AH, Seckin B (2012) Abscisic acid-regulated responses of aba2-1 under osmotic stress: the abscisic acid-inducible antioxidant defence system and reactive oxygen species production. Plant Biol 14:337-346

Pandey S, Fartyal D, Agarwal A, Shukla T, James D, Kaul T, Negi YK, Arora S, Reddy MK (2017) Abiotic stress tolerance in plants: myriad roles of ascorbate peroxidase. Front Plant Sci 8:581

Parra-Lobato MC, Fernandez-Garcia N, Olmos E, AlvarezTinaut MC, Gomez-Jimenez MC (2009) Methyl jasmonate-induced antioxidant defence in root apoplast from sunflower seedlings. Environ Exp Bot 66:9-17

Passaia G, Queval G, Bai J, Margis-Pinheiro M, Foyer CH (2014) The effects of redox controls mediated by glutathione peroxidases on root architecture in Arabidopsis thaliana. J Exp Bot 65:1403-1413

Piotrowska A, Bajguz A, Godlewska-Zylkiewicz B, Czerpak R, Kaminska M (2009) Jasmonic acid as modulator of lead toxicity in aquatic plant Wolffia arrhiza (Lemnaceae). Environ Exp Bot 66:507-513

Pons R, Cornejo MJ, Sanz A (2013) Is ABA involved in tolerance responses to salinity by affecting cytoplasm ion homeostasis in rice cell lines? Plant Physiol Biochem 62:88-94

Qu A-L, Ding Y-F, Jian Q, Zhu C (2013) Molecular mechanisms of the plant heat stress response. Biochem Biophys Res Commun 432:203-207

Rakitin V, Prudnikova O, Rakitina T, Karyagin V, Vlasov P, Novikova G, Moshkov I (2009) Interaction between ethylene and $\mathrm{ABA}$ in the regulation of polyamine level in Arabidopsis thaliana during UV-B stress. Russ J Plant Physiol 56:147-153
Rivero RM, Kojima M, Gepstein A, Sakakibara H, Mittler R, Gepstein S, Blumwald E (2007) Delayed leaf senescence induces extreme drought tolerance in a flowering plant. Proc Natl Acad Sci USA 104:19631-19636

Roychoudhury A, Basu S, Sengupta DN (2012) Antioxidants and stress-related metabolites in the seedlings of two indica rice varieties exposed to cadmium chloride toxicity. Acta Physiol Plant 34:835-847

Ruelland E, Zachowski A (2010) How plants sense temperature. Environ Exp Bot 69:225-232

Ruelland E, Vaultier MN, Zachowski A, Hurry V (2009) Cold signalling and cold acclimation in plants. Adv Bot Res 49:35-150

Saruhan N, Saglam A, Kadioglu A (2012) Salicylic acid pretreatment induces drought tolerance and delays leaf rolling by inducing antioxidant systems in maize genotypes. Acta Physiol Plant 34:97-106

Sasse JM (2003) Physiological actions of brassinosteroids: an update. J Plant Growth Regul 22:276-288

Savenstrand H, Brosche M, Strid A (2004) Ultraviolet-B signalling: Arabidopsis brassinosteroid mutants are defective in UV-B regulated defence gene expression. Plant Physiol Biochem 42:687-694

Seo H, Li J, Lee S, Yu J, Kim K, Lee S, Lee I, Paek N (2007) The hypernodulatingntsmutation induces jasmonate synthetic pathway in soybean leaves. Mol Cells 24:185-193

Sharma SS, Kumar V (2002) Responses of wild type and abscisic acid mutants of Arabidopsis thaliana to cadmium. J Plant Physiol 159:1323-1327

Sharma MK, Kumar R, Solanke AU, Sharma R, Tyagi AK, Sharma AK (2010) Identification, phylogeny, and transcript profiling of ERF family genes during development and abiotic stress treatments in tomato. Mol Genet Genom 284:455-475

Sharma I, Pati PK, Bhardwaj R (2011) Effect of 28-homobrassinolide on antioxidant defence system in Raphanus sativus L. under chromium toxicity. Ecotoxicology 20:862-874

Sharma I, Ching E, Saini S, Bhardwaj R, Pati PK (2013) Exogenous application of brassinosteroid offers tolerance to salinity by altering stress responses in rice variety Pusa Basmati-1. Plant Physiol Biochem 69:17-26

Singh A, Prasad SM (2011) Reduction of heavy metal load in food chain: technology assessment. Rev Environ Sci Biol 10:199-214

Soares C, Sousa A, Pinto A, Azenha M, Teixeira J, Azevedo RA, Fidalgo F (2016) Effect of 24-epibrassinolide on ROS content, antioxidant system, lipid peroxidation and $\mathrm{Ni}$ uptake in Solanum nigrum L. under Ni stress. Environ Exp Bot 122:115-125

Song Y, Chen Q, Ci D, Zhang D (2013) Transcriptome profiling reveals differential transcript abundance in response to chilling stress in Populussimonii. Plant Cell Rep 32:1407-1425

Sousa DPF, Braga BB, Gondim FA, Gomes-Filho E, Martins K, Brito POB (2016) Increased drought tolerance in maize plants induced by $\mathrm{H}_{2} \mathrm{O}_{2}$ is closely related to an enhanced enzymatic antioxidant system and higher soluble protein and organic solutes contents. Theor Exp Plant Physiol 28:297-306 
Souza LA, Piotto FA, Nogueirol RC, Azevedo RA (2013) Use of non-hyperaccumulator plant species for the phytoextraction of heavy metals using chelating agents. Sci Agric 70:290-295

Souza LA, Camargos LS, Schiavinato MA, Andrade SAL (2014) Mycorrhization alters foliar soluble amino acid composition and influences tolerance to $\mathrm{Pb}$ in Calopogonium mucunoides. Theor Exp Plant Physiol 26:211-216

Souza LA, Piotto FA, Dourado MN, Schmidt D, Franco MR, Boaretto LF, Tezotto T, Ferreira RR, Azevedo RA (2015) Physiological and biochemical responses of Dolichos lablab L. to cadmium support its potential as a cadmium phytoremediator. J Soil Sediment. doi:10.1007/s11368015-1322-0

Sun ZH, Wen C, Chen ZY, Zhang QA, Fang L, Li JA, Jiang ST, Cao SQ (2011) A role for Ethylene-Insensitive 2 gene in the regulation of the ultraviolet-B response in Arabidopsis. Acta Physiol Plant 33:1025-1030

Suzuki N, Miller G, Salazar C, Mondal HA, Shulaev E, Cortes DF, Shuman JL, Luo X, Shah J, Schlauch K, Shulaev V, Mittler R (2013) Temporal-spatial interaction between reactive oxygen species and abscisic acid regulates rapid systemic acclimation in plants. Plant Cell 25:3553-3569

Suzuki N, Rivero RM, Shulaev V, Blumwald E, Mittler R (2014) Abiotic and biotic stress combinations. New Phytol 203:32-43

Tassi E, Pouget J, Petruzzelli G, Barbafieri M (2008) The effects of exogenous plant growth regulators in the phytoextraction of heavy metals. Chemosphere 71:66-73

Tian SK, Lu LL, Yang XE, Huang HG, Wang K, Brown PH (2012) Root adaptations to cadmium-induced oxidant stress contribute to $\mathrm{Cd}$ tolerance in the hyper accumulator Sedum alfredii. Biol Plant 56:344-350

Tognetti VB, Muhlenbock P, Van Breusegem F (2012) Stress homeostasis - the redox and auxin perspective. Plant Cell Environ 35:321-333

Torres MA, Dangl JL, Jones JD (2002) Arabidopsis gp91phox homologues AtrbohD and AtrbohF are required for accumulation of reactive oxygen intermediates in the plant defense response. Proc Natl Acad Sci USA 99:517-522

Tossi V, Lamattina L, Cassia R (2009) An increase in the concentration of abscisic acid is critical for nitric oxide-mediated plant adaptive responses to UV-B irradiation. New Phytol 181:871-879

Trujillo LE, Sotolongo M, Menendez C et al (2008) SodERF3, a novel sugarcane ethylene responsive factor (ERF), enhances salt and drought tolerance when overexpressed in tobacco plants. Plant Cell Physiol 49:512-525

Tuna AL, Kayab C, Dikilitas M, Higgs D (2008) The combined effects of gibberellic acid and salinity on some antioxidant enzyme activities, plant growth parameters and nutritional status in maize plants. Environ Exp Bot 62:1-9

Türkan I, Demiral T (2009) Recent developments in understanding salinity tolerance. Environ Exp Bot 67:2-9

Uquillas C, Letelier I, Blanco F, Jordana X, Holuigue L (2004) NPR1-independent activation of immediate early salicylic acid-responsive genes in Arabidopsis. Mol Plant Microbe Interact 17:34-42

Villiers F, Jourdain A, Bastien O, Leonhardt N, Fujioka S, Tichtincky G, Parcy F, Bourguignon J, Hugouvieux V (2012) Evidence for functional interaction between brassinosteroids and cadmium response in Arabidopsis thaliana. J Exp Bot 63:1185-1200

Wang YH, Wan LY, Zhang LX, Zhang ZJ, Zhang HW, Quan RD, Zhou SR, Huang RF (2012a) An ethylene response factor OsWR1 responsive to drought stress transcriptionally activates wax synthesis related genes and increases wax production in rice. Plant Mol Biol 78:275-288

Wang K, Zhang X, Ervin E (2012b) Antioxidant responses in roots and shoots of creeping bentgrass under high temperature: effects of nitrogen and cytokinin. J Plant Physiol 169:492-500

Wasternack C (2007a) Jasmonates: an update on biosynthesis, signal transduction and action in plant stress response, growth and development. Ann Bot 100:681-697

Wasternack C (2007b) Oxylipins: Biosynthesis, signal transduction and action. In: Hedden P, Thomas SG (eds) Plant hormone signaling. Annual plant reviews. Blackwell Publishing Ltd, Oxford, pp 185-228

Wasti S, Mimouni H, Smiti S, Zid E, Ben Ahmed H (2012) Enhanced salt tolerance of tomatoes by exogenous salicylic acid applied through rooting medium. OMICS 16:200-207

Wrzaczek M, Vainonen JP, Gauthier A, Overmyer K, Kangasjärvi J (2011) Reactive oxygen in abiotic stress perception-from genes to proteins. In: Shanker A, Venkateswarlu B (eds) Abiotic stress response in plantsphysiological, Biochemical and Genetic Perspectives. InTech, Croatia, pp 27-54

Wu L, Zhang Z, Zhang H, Wang X-C, Huang R (2008) Transcriptional modulation of ethylene response factor protein JERF3 in the oxidant stress response enhances tolerance of tobacco seedlings to salt, drought, and freezing. Plant Physiol 148:1953-1963

Xu S (2010) Abscisic acid activates a $\mathrm{Ca}_{2}{ }^{+}$-calmodulin-stimulated protein kinase involved in antioxidant defense in maize leaves. Acta Biochim Biophys Sin 42:646-655

Xu H, Wang X, Sun X, Shi Q, Yang F, Du D (2008) Molecular cloning and characterization of a cucumber MAP kinase gene in response to excess $\mathrm{NO}_{3}{ }^{-}$and other abiotic stresses. Sci Hortic 117:1-8

Yan F, Deng W, Wang X, Yang C, Li Z (2012) Maize (Zea mays L.) homologue of ABA-insensitive (ABI) 5 gene plays a negative regulatory role in abiotic stresses response. J Plant Growth Regul 68:383-393

Yang Z, Yu J, Merewitz E, Huang B (2012) Differential effects of abscisic acid and glycine betaine on physiological responses to drought and salinity stress for two perennial grass species. J Am Soc Hortic Sci 137:96-106

Yang Y-W, Chen H-C, Jen W-F, Liu L-Y, Chang M-C (2015) Comparative transcriptome analysis of shoots and roots of TNG67 and TCN1 rice seedlings under cold stress and following subsequent recovery: insights into metabolic pathways, phytohormones, and transcription factors. PLoS ONE 10:0131391

Yu LJ, Luo YF, Liao B, Xie LJ, Chen L, Xiao S, Li JT, Hu SN, Shu WS (2012) Comparative transcriptome analysis of transporters, phytohormone and lipid metabolism pathways in response to arsenic stress in rice (Oryza sativa). New Phytol 195:97-112

Yuan G-F, Jia C-G, Li Z, Sun B, Zhang L-P, Liu N, Wang Q-M (2010) Effect of brassinosteroids on drought resistance and 
abscisic acid concentration in tomato under water stress. Sci Hortic 126:103-108

Zhang XZ, Ervin EH (2008) Impact of seaweed extract-based cytokinins and zeatinriboside on creeping bentgrass heat tolerance. Crop Sci 48:364-370

Zhang LR, Xing D (2008) Methyl jasmonate induces production of reactive oxygen species and alterations in mitochondrial dynamics that precede photosynthetic dysfunction and subsequent cell death. Plant Cell Physiol 49:1092-1111

Zhang A, Zhang J, Zhang J, Ye N, Zhang H, Tan M, Jiang M (2011) Nitric oxide mediates brassinosteroid-induced ABA biosynthesis involved in oxidant stress tolerance in maize leaves. Plant Cell Physiol 52:181-192

Zhang YP, Zhu XH, Ding HD, Yang SJ, Chen YY (2013) Foliar application of 24-epibrassinolide alleviates high-temperature induced inhibition of photosynthesis in seedlings of two melon cultivars. Photosynthethica 51:341-349

Zhang Y, Zhang M, Yang H (2015) Postharvest chitosan-gsalicylic acid application alleviates chilling injury and preserves cucumber fruit quality during cold storage. Food Chem 174:558-563
Zhao FY, Hu F, Han MM, Zhang SY, Liu W (2011) Superoxide radical and auxin are implicated in redistribution of root growth and the expression of auxin and cell-cycle genes in cadmium-stressed rice. Russ J Plant Physiol 58:851-863

Zinta G, AbdElgawad H, Domagalska MA, Vergauwe L, Knapen D, Nijs I, Janssens IA, Beemster GTS, Asard H (2014) Physiological, biochemical, and genome-wide transcriptional analysis reveals that elevated $\mathrm{CO}_{2}$ mitigates the impact of combined heat wave and drought stress in Arabidopsis thaliana at multiple organizational levels. Glob Change Biol 20:3670-3685

Zong X-JZ, Li D-P, Gu L-K, Li D-Q, Li L-X, Hu X-L (2009) Abscisic acid and hydrogen peroxide induce a novel maize group C MAP kinase gene, ZmMPK7, which is responsible for the removal of reactive oxygen species. Planta 229:485-495

Zörb C, Geilfus C-M, Mühling KH, Ludwing-Müller J (2013) The influence of salt stress on ABA and auxin concentrations in two maize cultivars differing in salt resistance. J Plant Physiol 170:220-224 